\title{
The leadership of the Kiai in Facing the Globalization of Education in Islamic Boarding School
}

\author{
Ahmad Taufiq \\ STKIPNU Kabupaten Tegal Jl. Ahmad Yani No. 21 Procot Slawi \\ taufiqstkipnu69@gmail.com \\ Article received: November 2020; revised: April 2021 ; accepted : April 2021
}

DOI : 10.17977/um025v5i22021p61

\begin{abstract}
The leadership of the Kiai is very important in the management of Islamic boarding schools, especially the salafiyah Islamic boarding schools, which of course depend heavily on the leadership of the Kiai. The flow of globalization which is a very fast change also affects the pattern of education and of course Islamic boarding schools as one of the national education entities. The influence of globalization in Islamic boarding schools mainly occurs in the pattern of education and leadership models which also affect all aspects of pesantren life. This change also occurred in the Salafiyah Islamic boarding school, which eventually implemented paperless learning because some books had become e-books that could be edited for student learning. In the end, Kiai's leadership became a milestone in the rise of Islamic boarding schools in the era of globalization.
\end{abstract}

Keywords: Leadership of Kiai, globalization of education, salafiyah Islamic boarding school

The emergence of a change is a necessity, a sunnatullah that cannot be denied. The process of structural change and development that drives momentum is known as globalization (Azra, 2009: 14-18), quoting social theorists such as Held and Mc. Grew, that the term globalization often refers to the expansion of a wider scale, extraordinary growth, a profound and very rapid impact on the flow between regions, and patterns of social interaction. Paul Tarc and Martin Carnoy developed the study of the globalization of education by emphasizing broader changes in political, economic, and social contexts. They strive to relate the pedagogical concept image with previous descriptive experiences as a teacher in international schools (Tarc, 2012), improve access to basic education, and participate in a comparative national education system that places more emphasis on the science curriculum (Cornoy, 2012). Paul Tarc (2012)

The national education system in Indonesia is increasingly moving to face the globalization of education in the future. There are two main types of Islamic schools in Indonesia: madrasah (Islamic day schools) and pesantren (Islamic boarding School). Here we will only discuss pesantren, but it will be noted that the two are not mutually exclusive or separate institutions: it is not uncommon for students in madrasas to simultaneously become students at the pesantren, and return respectively (Parker \& Raihani, 2011)Indonesia embarked on a journey to democracy. This journey involved the decentralization of education from 2002. The new school-based management (SBM.

The process of globalization is very complex and dynamic so that it can unite the nations of the world, from a political, social, economic, cultural, and environmental perspective without losing the existence and sovereignty of their respective countries. This integration is of course with the advancement of modern science and technology, especially communication and information technology. This process then emerges events, events, or policies in the country that are easily recognized by other countries (Nata, 2009). The education sector is also affected by the current globalization. According to Pieterse (2007), one of the global phenomena is that education is a globalization discourse to meet the needs of the global economy. In this perspective, globalization is considered as a medium that makes intercultural relations possible. 
Although the concept of globalization is not new, in the new millennium it has accelerated to become a central driving force behind the rapid, social, political and economic changes that are re-shaping modern societies but which will also impact heavily on education. The continuing trend towards a global economy has led to globalization knowledge, which is little affected by the boundaries between what is developing and what is less developed countries, thus bringing with it the potential to create knowledge accessible to all parties including Islamic boarding schools (Moloi et al., 2009).

The way of life of humans has changed, causing changes that have an impact on education throughout the world (Vulliamy, 2000) According to Joul Spring (2009), one of the phenomena of the globalization of education is a global discourse on fulfilling economic needs which will cause public concern, namely education with a secularization model controlling religious education so that the issue of secularism is increasingly difficult to overcome (Wayong, 2007).

The globalization of education is a dilemma for Islamic boarding schools. On the one hand, Islamic boarding schools must implement their salafiyah education and on the other hand, the demands of the globalization era require skills and legalization in the form of diplomas, but how many Islamic boarding schools have responded to this very elegantly and still establish public schools but keep running its salafiyah curriculum in one place. Even though some Kiai oppose the concept of globalization by only implementing the salafiyah curriculum in their Islamic boarding schools. So, how many aspects are observed in the research, namely the process and role of the Kiai's leadership in facing global change, especially those related to the leadership attitude taken by the Kiai in making policies and decisions.

The purpose of this study was to determine the leadership of the Kiai in facing the globalization of education in Islamic boarding schools.

\section{METHODS}

This research uses a qualitative approach in the form of ethnography, which is an approach to develop an understanding of the daily activities or behavior of a group of people in a certain setting. The paradigm used is post-positivist, that is, a research perspective that is interpretive, constructive, and takes place in a natural setting.

The research assumption is that the Kiai's leadership is very influential in the direction of the development of education in Islamic boarding schools. Seeing Kiai leadership as a culture does not only involve knowledge but also from the context of daily life patterns. Knowledge of this model is not only obtained from the school but is based on the life experience of a Kiai.

The researcher seeks to study the patterns of behavior, traditions, and views of life of the Kiai because from this, the Kiai's leadership model is seen naturally. This ethnographic approach to research tends to lead to field ethnography (field ethnography) because researchers study and explore a group in their daily lives directly in a natural setting.

The research sample is Islamic boarding schools that have implemented modern general education (as a result of the globalization of education) but still run the salafiyah curriculum. The Islamic boarding school, which only applies the salafiyah curriculum in its school, does not neglect the figure of Kiai as the caretaker of the boarding school to explore its leadership role in facing global change. The number of Islamic boarding schools chosen as the samples were the Al-Hikmah 2 Benda Brebes Islamic Boarding School and the Al-Asy'ariyah Wonosobo Islamic Boarding School which had implemented general education globally. However, it does not rule out salafiyah education. There is also a boarding school al-Fadlu Kaliwungu Kendal, Central Java with a distinctive Kiai figure, namely KH. Dimyati Rois who continues to implement salafiyah education in the midst of the onslaught of globalization efforts in the field of education. 


\section{RESULTS AND DISCUSSION}

Education is influenced by globalization in its components. Globalization affects education in terms of curriculum, teaching strategies, leadership, management, administration, assessment, evaluation, and certification (Sudarya, 2012). The factors causing the emergence of globalization are political policies, instruments of global pressure, namely: (1) political policies, during this reform period there has been a change from a centralized system of government to a decentralized government; and (2) instruments of global pressure, as a historical phenomenon, that the process of global change does not only occur after World War II.

Islamic boarding school as an educational institution has its own characteristics. Islamic boarding school is an original Indonesian educational institution that is older than the Indonesian state. Islamic boarding schools are also the center for broadcasting Islam in Indonesia. The leadership of the Kiai is considered to provide an influence from the stimulus of authority as a boarding school leader who focuses on the charisma of a Kiai. Susanto (2007) states that the Kiai of the Islamic boarding school has great influence and appreciation because of its role in society. The role of Kiai as the Islamic boarding school caretaker makes him a very strategic position. The kiai has a role regarding many aspects, from social, political, cultural, especially the role in the religious field. The kiai is also a central figure in the Islamic boarding school sphere. In this case, Kiai is the CEO of the Islamic boarding school who has the task of not only managing but also teaching (Sulaiman, 2016).

The main roles of the Kiai are as scholars, caregivers, and educators. Apart from this main role, the Kiai is also the liaison of the community, leaders, and even community leaders in the religious field. The complex demands of a Kiai require that he be able to position himself in various situations that occur. This distinguishes a Kiai from other community leaders, namely in the relationship of social interactions between Kiai, ustadz, and students (Ma'rufah, 2014). Because of the heavy-duty of a Kiai, a Kiai is demanded of capability, dedication, and a strong commitment to carry out this multi-functional role (Arifin 2015). The Kiai leadership study cannot be separated from the need for an understanding of the substance of education, but also as a guide and educator of the community.

The pattern of salafiyah education in this section, the example described is Pesantren Al-Fadlu Kaliwungu Kendal founded by KH. Dimyati Rois in 1985, a native scholar of Tegal Glagah, Brebes Regency who was born in 1925 H. KH. Dimyati with Hj. Tho'ah bint Ibadullah Irfan (Kendal).

The al-Fadlu Islamic boarding school in the outside learning system always carries out the tradition of deliberation and the tradition of lalaran. (1) The deliberation tradition is a learning activity which is carried out at 19.30-22.00 WIB; (2) The lalaran tradition is that students gather in their respective classes and then read the lesson in the form of nadzaman (sya'ir form) together and chant, aiming to make it smooth and easy to memorize. Before lalaran first take 10 minutes after the bell, bring nadhaman; and (3) The tradition of reciting the Koran with apshahi, the al-Fadlu pesantren with the yellow book study tradition as a reference. This can be seen from the persistence of the students at the time of nyantri (Harun Ar-Rosyid) at the pesantren.

The activities of the students in participating in school activities can be explained as follows: (1) Preparation to leave and enter the room after the first bell rings; (2) Before taking the roll call, lalaran first then began to take attendance at 07.30 and 08.00 starting from lessons until 09.30 (first session) and in the teaching and learning process until you entered again at $08.00 \mathrm{hrs} .10 .30-12.00$ is the second session; (3) to pick up Ustadz at 08.00, and (4) Contact Mustahiq (homeroom teacher) or madrasah administrators if the cleric is unavailable.

The learning method in this case at the Al-Fadllu Islamic boarding school does not use assistive devices such as LCDs, computers, and others but in delivering the material using Indonesian because the origin of the students is not focused on the Central Java region, some from Sumatra, Jakarta, West Java, of course, they do not understand Javanese. The number of classes in the al-Fadlu Islamic boarding school consists of four classes, namely; Preparatory madrasah must be taken for 2 years; Madrasah Tsanawiyah 3 years; Madrasah Aliyah 3 years; Ma'had Ali 2 years. As above in the distribution of picture subjects: $3 . \mathrm{a} 4$, as for the legality or diploma issued by the boarding school itself. 
Implementation of the Al-Fadlu Islamic Boarding School Curriculum in Jagalan Kaliwungu Kendal. Pesantren does not use a national (general) curriculum, the curriculum applied is the pure salafiyah curriculum from the Islamic boarding schools. The lesson from this Islamic boarding school was still the same, namely the salafiyah books (Kh. Dimyati Rois).

Pesantren al-Fadlu is a traditional Islamic boarding school where the financial source only consists of funds in the form of donations from the community, finance from Kiai's own business, namely the results of planting rice fields and gardens because Kiai has very large fields, such as onion plants and shrimp ponds, then finance. from the results of PT Tour Arafah which is engaged in the Hajj and Umrah sector, some of the results are donated to the needs of the pesantren. The administrative finance of the santri, both from the payment of syahriyah students or payment of $i$ 'anah donations from the santri guardian, is only for financing the honorarium of the ustadz (Harun Ar-Rasyid 2017).

The pattern of khalafiyah education, the existence of this pesantren since the pioneering period, in 1832-1859 AD. There was no concept of al-Asy'ariyah, but there was no concept of al-Asy'ariyah, it was only provided a place for the community to pray which was called a padepokan which was then changed to the ta'lim al-Hidayah assembly and after the leadership of KH. Muntaha al-Hafidz changed again to the al-Asy'ariyah pesantren. The Wonosobo Padepokan was founded by KH. Muntaha bin Nida Muhammad in 1832 AD Initially, he founded the mosque as a place of worship and studied Islam in Karangsari hamlet, Ngebrak, Kalibeber. Persistence and tenacity also the patience of KH. Muntaha bin Nida, finally the people of Kalibeber and its surroundings gradually embraced Islam on their own conscience. They gradually left immorality which had become a bad habit, such as gambling, cockfighting, drinking khamr and others, then this hermitage had more and more students and followers so that the santri hermitage was unable to accommodate it, so that known booths began to be built. as a santri hermitage (KH. Mukhotob Hamzah 2018)

The total number of students in the al-Asy'ariyah pesantren is 3000 students, consisting of how many boarding blocks in each block, there are several levels, namely; Takhasus SD and MI, Takhasus SMP and MTs, Takhasus SMA and SMK, student blocks, salafiyah and tahfidz blocks and workers' blocks. Santri with their own arrangements run according to the rules and laws made by the board of the boarding school and the Kiai tashkheh then agreed and obeyed together (Dawim Istifadah, 2018).

Changes in learning methods are marked by symbols from salafiyah to modern by integrating Islamic religious subjects with general subjects. In this case, it was developed by KH. Muntaha Al-Hafidz or commonly known as mbah Mun, is a 'Multidimensional and Charismatic Ulama (Dawim Istifadah). The Al-Qur'an education system at the elementary, junior high school level, tahfidz al-Qur'an in the future can memorize the Al-Qur'an, salafiyah children are held using the yellow book, there are also students who recite during the day on campus with cheer and at night reciting the Koran. The education system refers to the national education system, the basic curriculum used by SMP Takhassus al-Qur'an Kalibeber is the curriculum issued by the Ministry of National Education. The system of completeness of SMP Tahassus al-Qur'an Kalibeber has its own curriculum, namely the special curriculum which includes religious lessons (al-qur'an hadith, fiqh, aswaja, aqidah-morals, nahwu shorof and language lessons, namely Arabic (mukhadatsah) and English (conversation) (Dawim Istifadah, 2018).

The curriculum applied at the al-Asy'ariyah pesantren was previously an independent curriculum, namely a curriculum developed in the salafiyah period. The curriculum at Takahsus Al-Qur'an High School at the al-Asy'ariyah Islamic boarding school is a curriculum issued by the Ministry of Education and Culture of the Republic of Indonesia (Kemendikbud RI) and the education system is adapted to the National Education System (Sisdiknas) (KH. Abdurahahim, 2017) .

The evaluation and grading system for boarding schools al-Asy'ariyah Wonosobo is through summative tests carried out with final semester exams and normative tests carried out in two stages, namely: (1) The al-Qur'an tahfidzu evaluation system with the Sorogan system, namely one deposit one by one. , and the bandongan system, namely with sema'an; and (2) by memorizing and depositing material. In learning Madrasah Takhassus Al-Qur'an Wonosobo prioritizes the aspect of memorizing the Quran so that it can be said to be a superior program. The scoring system is almost the same as 
through summative tests which are held per semester in the Final Semester Examinations starting from the beginning of the new academic year.

The ideal (mixed) pesantren education pattern, for example the Al-Hikmah 2 Islamic boarding school. A pesantren that can be classified into a mixed pesantren pattern (Rouf, 2016) between salafiyah and khalafiyah. Pondok Pesantren Al Hikmah Benda Sirampog Brebes, Central Java was founded in 1911 AD by K.H. Kholil bin Mahali (Sholahuidin, 2015). In 1922 AD he was assisted by a kyai named K.H. Sukhaemi bin H. Abdul Ghoni.

In the al-Hikmah 2 Islamic boarding school it is also well known for developing three sciences, namely sharia, essence, and kanuragan (martial arts). Santri are fond of knowledge and continue to be channeled by reading a lot of books and books of other knowledge and being diligent in following tabarokan. Tabarokan is a blessing while studying religion. The time that is often used by sanrtri for tabarokan is during the holy month of Ramadan. Usually for one full month in the month of Ramadan, students recite the Koran with tabarokan at Kiai-Kiai (Solahudin, 2017).

Most of the students follow the Kiai, followers of the Sadzilyah Tariqah. This tariqah has a light teaching or practice to do for the congregation. Teaching adherents to always abandon all immoral acts, always maintaining compulsory worship, this tariqah also teaches dhikr, a day and a night with how many dhikr required is istighfar 100 times, salawat to the prophet Muhammad is also 100 times, as well as other dzikir (Hidayati, 2017 ).

Al-Hikmah 2 Islamic boarding school is led by a primary caregiver assisted by 5 assistants (badal) who handle daily technical areas which include: (1) Assistant in the field of education and recitation (2) Assistant for Security (3) Assistant for Research and Development (4) Assistant for Equipment (5) Assistant for Public Relations. The highest Kiai structure is the caregiver council chaired by KH. Sholahudin Masruri and the board of guidance for the pesantren were chaired by H. Itmamudin Masruri, then Umu Izatur Rizqi as the general chairman or head of the pesantren village.

Organizational activities emphasize the interests of the communication process, decision making, achievement evaluation, career, and socialization (Gibson, Invancevich and Donnelly, 1997). Pesantren al-Hikmah 2 has a family organization whose members consist of a board of carers, a board of advisors, and some senior santri, where the organization's activities aim to discuss issues that exist to make a joint decision, and also to familiarize the family. The Kiai organization meetings and gatherings are held once a week every Friday and for a meeting of all teachers and administrators every 14th of a month (Aminudin, 2018).

The al-Hikmah 2 Islamic boarding school alumni organization also communicates through alumni meetings. The head of al-Hikmah 2 Islamic boarding school alumni until 2018 is KH. Syamsul Arifin and the alumni forum with the name HIMMAH (Himpunan Mutakhorijiin al-Hikmah). Alumni meeting every once a year, which is every 1st of Muharram to coincide with the KH haul event. Musruri deceased. The meeting agenda is to discuss the existence of the al-Hikmah 2 Islamic boarding school, so all alumni are required to provide information to the wider community about the existence of the alHikmah 2 Islamic boarding school, both programs and facilities in al-Hikmah 2 (Arifin, 2017). Alumni who have been successful will inspire and students can be motivated to be more active in deepening their knowledge, and usually, alumni of al-Hikmah 2 santri are given invitations to come to the pesantren when there are haul, halaqoh, haflah ends Al-Hikmah 2 alumni in 2016 M., have generally graduated more than 20,000 alumni, they are spread throughout the islands of Java, Sumatra, and Sulawesi who have served in the community.

Based on the information of Aminudin (2018), the activities of students and alumni at the al-Hikmah 2 Islamic boarding school are very related, because alumni support for the leadership of the pesantren can affect the power of Kiai's authority. The activities of the santri at the al-Hikmah 2 Islamic boarding school do not limit the registration of receiving students who are strictly selected, in order to restore the image of the pesantren by dismissing the impression that the pesantren is a cure for problem children, a place for the education of children who are weak thinking. All santri must live in the boarding school and follow the rules and implement the boarding school program (Affandi, 2017). 
The total number of students is 10,000 students consisting of MI, MTs, SMP, MA, SMA, SMK, MMA, Ma'had Aly, Akper, and STAI al-Hikmah levels. Santri come from various regions, West Java, Central Java, East Java, Sumatra, Kalimantan, Sulawesi and some even from Malaysia.

Learning is a learning process that encourages understanding of education psychologically with the conclusion that learning is equated with behavior change (Hansen, 2000). The learning method at MMA is the wetonan method like most salafiyah pesantren; reading teacher, student ngabsahi (giving meaning). Through the sorogan method; students read the text and interpret each word in front of the ustadz or teacher (Aminudin, 2018). Every time learning, the teacher provides opportunities for students to explain their lessons. This aims to assess the ability and correctness of students' understanding. The study time starts from $07.05-07.30$ reading the Koran and muhafadzah amrity / alfiyah; $07.30-12.15$ and teaching and learning activities (KBM); 16.00 - 17.30; Deliberation 08.00-10.00. General Muhafadzah class I - VI (every Friday morning).

MMA is a salafiyah school in al-Hikmah 2 which enters the morning and requires reading the Koran before studying (Affandi, 2018). The kiai in leading the pesantren in Pesantren al-Hikmah 2 Education is assisted by highly qualified teaching staff and almost the average Middle East alumni. Then the policy possibilities are also very high quality. The prospect for the future of this pesantren is to follow PMA on pesantren and religious education whose goal is that the salafiah pesantren is still reciting the Koran and their graduation is recognized by the government, in this case the Ministry of Religion.

The teaching and learning process in general education, namely SMK Wicaksana Al Hikmah 2 Sirampog, is carried out from morning to evening according to the hours needed according to the curriculum. Media models and learning resources in learning use (1) computer media, (2) audiovisuals, and learning resources are books as references in accordance with the curriculum and empirical experience (Affandi, 2015). Examples of teaching books have been assisted by using an iPad or tablet, but children are still required not to abandon learning morals.

Participation is an activity that provides a set of rules for determining policies in managing pesantren. The actual Kiai generation has been instilled since the Kiai children in the Islamic boarding school, how to gain knowledge from teachers, how to lead organizations in the pesantren starting from room administrators, complex administrators, and dormitories. has been absorbed in learning time, namely about leadership and participating in Islamic boarding schools (Suwarto, 1999).

The curriculum consists of three parts, namely, (1) the Islamic boarding school curriculum which is mu'addalah from the Ministry of Religion, this curriculum is applied to the Mu'alimat salafiyah (MMA) madrasah (2) the Ministry of Religion curriculum, and (3) the Ministry of Education and Culture curriculum. The curriculum used is the curriculum of the Education Office and the Health Office.

Pesantren al-Hikmah 2 manages education from early childhood education (PAUD) to MTs, SMP, MA, SMA, and SMK and college levels. As proof of al-Hikmah 2's commitment to managing education, namely first establishing a kindergarten (RA / TK) in 1998 received an operational permit from the Brebes district education office and was named TK al-Hikmah 2, then in 2006 school accreditation and got an A. with the curriculum at the level of education unit (KTSP) kindergarten (TK) al-Hikmah 02 Benda (Affandi, 2018).

Until now, the pesantren, which is located at the foot of Mount Slamet, has more than 10 thousand students who in 2018 AD came from all over Indonesia. Learning at the MTs, SMP, MA, SMA, and SMK levels with the 2013 curriculum. This is a systematic process of obtaining (scientific) knowledge by observing, analyzing, gathering information, associating, communicating, and implementing. On the basis of this fact, this curriculum learning will be a dynamic guide for the implementation of education and teaching at Al-Hikmah 02 (Hidayati, 2018).

The MMA scoring and grading system at the al-Hikmah 2 Islamic boarding school is that it must meet the predetermined requirements for class promotion, among others, (1) principal value, namely the subject matter which has an average value of not less than 6.0 (Nahwu, Shorof, Fiqih, Monotheism, morals) or having a value of 30 from the number of basic materials, (2) non-academic, including: attendance should not be more than 10 absent per semester (school attendance \& deliberation); Not hit 
by cases; active mukhafadzah and daily recitation, (3) memorization, memorization criteria are a) for class SP to memorize Hidayah Ash Shibyan to Khatam \& Al 'Imrithy 1-120 verses (as a requirement for taking class II test), b) for class I memorized Hidayah Ash Shibyan and Al 'Imrithy 1-120 verses, c) for class II memorize Al' Imrithi 1-245 verses, d) for class III memorize Alfiyah 001-350, d) for class IV memorize Alfiyah 001-700, e) for class V memorizes Alfiyah 001-1002, f) for class VI memorizes Alfiyah 001-1002 (Affandi, 2018).

The financial sources of the al-Hikmah 2 Islamic boarding school consist of; (1) Financial sources are obtained from outside the pesantren, namely special donors, waqf or grant funds as well as from the government which is not binding. Regarding the finances of the al-Hikmah 2 pesantren building, the funds obtained from the Kiai themselves and mutual funds from dzuriah (Kiai descent) dues and also assistance from alumni and generous people According to Aminudin, sometimes unexpectedly Kiai was building a pesantren with a large building capacity, suddenly someone sent as much as one truck of cement and iron.

The process of becoming a Kiai in al-Hikmah 2 is not as easy as through appointment or dismissal, but must meet the existing requirements and agreements, and must also have the ability as a leader, namely the habit of reading and studying yellow books and enriching knowledge, so that they are able to complete all the problems that arise, both in the pesantren, society, and organizations (Solahudin, 2016). Obedience, willingness to review and study are the initial requirements or basic knowledge of the Kiai, and during the recitation, he always has a moral attitude (maintaining politeness and ta'dzim to the teacher), and the books that are read include the book ta'lim muta'allim.

The leadership of the Kiai, although it is a matter of society's assessment of a particular individual from the point of view of the existing social system, the relationship between the individual elements and the offspring (genes) becomes an influence in the social system, this is the main factor that can explain leadership, this can be interpreted, as long as an individual who is said to be able to mulang koran, tarekat, riadhoh expert, genetics and society, the leader is considered to fulfill the various needs of the social system and the community that supports him, as long as he can be said to have succeeded in maintaining his emotional ties with his followers so that leadership can continue. Perubahan Institusi Pendidikan Salafiyah

Changes in institutions since the existence of policy policies made by the government influenced the Al-Fadlu Kaliwungu Islamic Boarding School to develop the education system, not only by using the halaqah system but using the bandungan, sorogan, deliberation, lalaran system, and more and more enthusiasts to read the yellow book not only in Even among the students, even from the surrounding community, they also want to deepen their religious knowledge through classical books. KH Dimyati continued to develop the salafiyah pesantren to his generation and the al-Fadlu pesantren always strived to maintain the form of salafiyah. Along with changing views and insights on global developments and also on the policies of the government of the Republic of Indonesia in this case is the Ministry of Religion of the Republic of Indonesia, finally this boarding school issued a diploma that is parallel to MTs, MA with mu'adalah at the Ministry of Religion (Harun Ar-Rasyid , 2016).

Different in Pesantren al-Asy'ariyah from generation to generation, the leadership of the Kiai still maintains manhâj salafiyah and studies of the Koran sciences with a little innovation by adding formal schools, namely establishing TK Roudlotul Athfal in 1960 and Madrasah Ibtidaiyyah Ma'arif Kalibeber 1960. (KH. Abdorahman, 2016). Established Madrasah Tsanawiyah Kalibeber and Madrasah Aliyah Ma'arif in the boarding school environment in 1962. In 1967, Madrasah Tsanawiyah was diverted following 1968 Madrasah Aliyah was also negated. Changes that have become a necessity for the times have forced or awakened the pesantren community to make adjustments in order to remain in tune with the evolution of society. Institutional changes, for example, the pesantren by changing the classical system, then changing the madrasah system again. 
The progress of this pesentren was very rapid under the guidance of $\mathrm{H}$. Masruri, this was marked by the establishment of formal education institutions such as MTs I (1964), Madrasah Diniyah Awaliyah (MDA), and Madrasah Diniyah Wustho (MDW) in 1966, then MMA in 1966, MA I in 1968 TK Roudlotul Athfal in 1978, MTs 2 and 3 in 1986, SMA in 1987, Takhasus Qiroatul Polar college in 1988, MTs 4 and 5 in 1989, MA 2 in 1990, STM in 1993, Madrasah Aliyah Khusus (MAK) in 1995, AKPER in 2002 and the Al-Hikmah School of Tafsir Science 2010. The development of the Al-Hikmah Islamic boarding school is getting faster, so the generation of KH Masruri's sons and daughters took the decision to split the foundation into two, namely al-Hikmah 1 and Al-Hikmah 2. This decision is based on the desire to maximize service optimally. In 2006, the Notary Deed No. 57 dated 19 June 2006 concerning the Establishment of the Al-Hikmah 2 Islamic Boarding School Education Foundation. As the Head of the Foundation is H. Shalahudin Masruri who is KH's eldest son. Masruri Abdul Mughni. Meanwhile, the AlHikmah 1 Islamic Boarding School Education Foundation is chaired by KH. Labib Sodiq. And since then until his death. KH. Masruri Abdul Mughni 2011 M. was more focused on serving at Pesantren Al-Hikmah 2, continued by KH. KH's first son Shalahudin. Masruri, an alumnus of Ma'had Aly Makkah.

\section{Change in the Orientation of Salafiyah Education}

The change in orientation to the residents of the Salafiyah al-Fadlu Kaliwungu boarding school was not so prominent, but it is still in the corridor of tafaqquh fi al-din. Al-Fadlu Islamic boarding school is a traditional Islamic boarding school to explore Islamic religious knowledge and practice it as a guide for daily life and has also contributed to the intellectual life of the nation. The implementation of the Al-Fadlu Islamic Boarding School Curriculum after it was confirmed that it did not use the Ministry of Education and Culture or the Ministry of Religion curriculum. Independent curriculum as a stipulation of pure salafiyah pesantren from Islamic boarding schools (Miftahudin, 2016). So the lesson from the Al-Fadlu Islamic boarding school was established until now it still maintains the salafiyah pattern. Pesantren al-Fadlu always strives to maintain the purity of the salafiyah, but does not stop to make changes. The orientation of al-Fadlu always makes a change by cooperating with both private and state religious colleges so that their santri alumnus can enter higher education.

The change in orientation to education at al-Asy'ariyah Wonosobo was marked by symbols from salafiyah to modern by integrating Islamic religious subjects with general subjects. The innovation was developed by KH. Muntaha Al-Hafidz or commonly called Mbah Mun is a 'multidimensional and charismatic' Ulama, he is also one of the 'well-known scholars as musrsyid al-Qur'an which is always authentic to Rasulullah SAW.

Globalization has changed the mindset of the leadership of the Kiai and the pesantren community. Pesantren now are no longer tafaqquh fi al-din, teachers are also affected by changes, namely, initially only ta'abud or worship develops into career orientation, for example, there are bosses, teacher certification and others, so that teachers or ustad have a target of teaching hours according to their portion teaching, in terms of the curriculum has also changed (A Sobirin, 2016). The orientation of the use of the curriculum in the al-Asy'ari Islamic boarding school is tailored to the needs of the community and according to government political policies or the national education system.

Pesantren al-Hikmah 2 has the vision and mission of the pesantren and makes the pesantren provide benefits (inspiration/foundation) in the development of the education, teaching, and da'wah system. Al-Hikmah 2 prepares Islamic human resources who understand the science of religion (faqih fi al-din), are strong in religion (mutamassik bidinihi) and are noble in behavior (uswatun khasanah and akhlaq al-karimah), foster healthy, Islamic community life and develop and preserving Islamic values (Affandi, 2018).

Based on the vision and mission of the al-Hikmah 2 Islamic boarding school, KH. Sholahudin places more emphasis on science and technology that affect education because globalization has tremendous 
implications for knowledge, education, and learning. So pesantren al-Hikmah 2 is committed to developing pesantren by holding superior programs as one of the changes in the orientation of the pesantren to the curriculum, namely; (1) The study system, students at the al-hikmah Islamic boarding school, besides having to understand classical Islamic references, also explore current references available in 3000 Islamic book titles; (2) Daily communication between the students and the ustadz is conditioned to use Arabic or and English. Santri in this program are localized in a dormitory, and the supervisors in this program are graduates of the Middle East and well-known language institutions from Pare, East Java; and (3) optional skills, each student is equipped with one skill of various skills such as fashion, fisheries, gas, and electric welding, orchid farming, English, computer operators (equivalent to D1) $30 \%$ theory and $70 \%$ practice, and as a supporting application for this skills, the program is by holding street vendors in government agencies, companies, and industries.

\section{Quality and Learning Methods of Santri}

Seeing the increasing number of students every year, Madrasah Tsanawiyah (MTs) Al-Hikmah 2 Benda must strive to further improve the management and quality of education, including improving the quality of facilities and infrastructure for learning and teaching activities including classroom facilities and infrastructure, computer laboratories, science, mathematics, language, multimedia, and infrastructure for extracurricular activities (extracurricular activities) (Najib, 2015). If it is observed from the increase in the number of students from year to year in each of these institutions it can be seen in the table below Table 1.

Table 1 The Development of the Number of Students at the Al-Hikmah Islamic Boarding School 2

\begin{tabular}{ccccccccc}
\hline & \multicolumn{7}{c}{ Santri/Student } \\
\cline { 2 - 7 } Year & \multicolumn{7}{c}{ Ministry of Religion } & \multicolumn{7}{c}{ Ministry of Education } & \multirow{2}{*}{ MI } \\
\cline { 2 - 7 } & MI & MMA & MTs & MA & SMA & SMK & MHS & Total \\
\hline $2009 / 2010$ & 457 & 233 & 233 & 935 & 210 & 152 & 45 & 2.265 \\
$2010 / 2011$ & 467 & 284 & 284 & 696 & 141 & 284 & 11 & 2.167 \\
$2011 / 2012$ & 476 & 233 & 329 & 763 & 179 & 329 & 56 & 2.365 \\
$2012 / 2013$ & 514 & 284 & 363 & 856 & 171 & 363 & 120 & 2.671 \\
$2013 / 2014$ & 457 & 329 & 696 & 1025 & 242 & 423 & 118 & 3.290 \\
$2014 / 2015$ & 467 & 363 & 763 & 979 & 182 & 188 & 119 & 3.061 \\
$2015 / 2016$ & 476 & 419 & 829 & 289 & 158 & 419 & 107 & 2.697 \\
$2016 / 2017$ & 514 & 482 & 826 & 864 & 154 & 512 & 98 & 3.450 \\
$2017 / 2018$ & 520 & 555 & 824 & 829 & 139 & 520 & 102 & 3.489 \\
\hline
\end{tabular}

There is an oral exam with examiners from the public, it can be parents / neighbors / guardians of other students, so there is no manipulation. Mualimat is used to being trained in community activities such as hoeing, craftsmen, and others. So that when they graduate they are also ready to enter the community. In responding to the challenges of change and various needs of society, Islamic boarding school alHikmah 2 has historically undergone changes, especially following government political policies which have always had a relatively dominant influence, this is due to socio-economic changes which include: updating of materials and curriculum education and content of Islamic boarding schools by including general subjects and skills; reform of the education system and methodology; change in function, where the function of religious education also includes that of the economy. KH. Masruri Abdul Mughni has many strategies and steps in advancing and running his grandfather's heritage boarding school. He always looks for various fresh innovative ideas to maintain the existence of Al-Hikmah 2. His desire to advance Islamic boarding schools is adjusted to the demands of the ever-developing world of work (Affandi, 2016).

This is what we can finally see in the educational institutions he founded, complete and professional. Education is a field of struggle for Kiai Masruri, as evidenced by the rapid progress of Al-Hikmah 
Islamic boarding school education, the success of his struggle in the field of education can be seen from the number of formal educational institutions that are established under the Al-Hikmah Foundation. The educational institutions are Kindergarten, MI, Madrasah Diniyah Awaliyah, and Wustho, Madrasah Muallimin / Muallimat (MMA), MTs, MA, SMP, SMA, STM, SMK, AKPER, Perguruan Takhasus Qiroatul Kutub (Ma'had Aly). The change in the attitude of the Kiai at pesantren al-Hikmah 2 in the field of education is an interesting thing from KH Masruri's thinking by combining the pesantren curriculum with the educational curriculum under the Ministry of Religion and the Ministry of Education and Culture. The integration of the three curricula has become Kiai Masruri's foresight in responding to the challenges of the times.

The analysis of this learning method is the beginning of the political policy in the government which is relatively dominant in the socio-economic changes stated by Gamal Abdul Nasir Z., regarding the development of materials, educational curricula, and content of Islamic boarding schools by developing general lessons and skills as well as developing the education system and methodology. Table 2 shows the analysis of learning methods in three Islamic boarding schools.

Table 2.3 Analysis of Learning Methods

\begin{tabular}{lcccccc}
\hline \multirow{2}{*}{$\begin{array}{c}\text { Learning } \\
\text { Method }\end{array}$} & \multicolumn{2}{c}{ Pesantren al-Fadlu } & \multicolumn{2}{c}{ Pesantren Al-Asy'ariyah } & \multicolumn{2}{c}{ Pesantren Al_Hikmah 2 } \\
\cline { 2 - 7 } Sorogan & Yes & No & Yes & No & Yes & No \\
Bandungan & $\sqrt{ }$ & - & - & $\sqrt{ }$ & $\sqrt{ }$ & - \\
Discussion & $\sqrt{ }$ & - & - & $\sqrt{ }$ & $\sqrt{ }$ & - \\
Memorization & $\sqrt{ }$ & - & - & - & $\sqrt{ }$ & - \\
Lalaran & $\sqrt{ }$ & - & - & $\sqrt{ }$ & - & $\sqrt{ }$ \\
Lecture & $\sqrt{ }$ & - & $\sqrt{ }$ & - & $\sqrt{ }$ & - \\
Task & $\sqrt{ }$ & - & $\sqrt{ }$ & - & $\sqrt{ }$ & - \\
Presentation & - & $\sqrt{ }$ & $\sqrt{ }$ & - & $\sqrt{ }$ & - \\
\hline
\end{tabular}

The era of globalization requires Islamic boarding schools to make improvements, although how many Islamic boarding schools have persisted with the methods they have implemented from generation to generation, such as the Al-Fadlu Kaliwungu Islamic boarding school. Classical learning methods are typical of the salafiyah Islamic boarding schools in Java. They apply the sorogan, bandungan, discussion, deliberation, memorization, practice, lecture methods and with new innovations giving assignments to students to recap the lessons that have been transferred by Ustadz to the students.

In contrast to what is applied in the Al-Asy'ariyah Wonosobo Islamic boarding school, the pattern of the boarding school which tends to be modern usually applies learning methods such as in public schools such as discussions, lectures, assignments to students and accompanied by presentation of subjects with projectors. Likewise with the Al-Hikmah 2 Benda boarding school, although they still apply the sorogan and bandungan methods, they also mix methodology by giving lectures, assignments, and presentations via LCD or projectors.

Changes in pesantren facilities are a development that occurs structurally at the al-Hikmah 2 Islamic boarding school from a conventional system to a contemporary system marked by changes in the learning system (Suparta, 2009). The facilities and infrastructure for the al-Hikmah 2 Islamic boarding school consist of students' dormitories, a magnificent mosque, a sports building, and a large study or classroom room equipped with a large parking area and an operational car garage for the Islamic boarding school. Educational facilities at the al-Hikmah 2 institution are equipped with modern classrooms, namely LCD, computer laboratories and student benches, whiteboards, then the infrastructure that supports the activities of students in studying at Islamic boarding schools, both in the form of classrooms and guardrails and other supporting infrastructure. 
Al-Hikmah 2 Benda has a modern building or building facilities and is equipped with a library of books and books because the salaf education pattern at the Al-Hikmah 2 Benda Islamic boarding school uses blackboards, classrooms do not use benches or tables and there is no laboratory space and there is no LCD because it is still traditional as a learning medium. Meanwhile, the Al-Hikmah 2 Benda Islamic boarding school is very modern, starting from a dormitory building, a mosque, classrooms equipped with AC and LCD as well as desks and study benches, then a whiteboard using a whiteboard equipped with a magnificent sports building. Likewise at the Al-Hikmah 2 Benda boarding school, because their education pattern tends to be modern and has modern buildings, air-conditioned rooms, representative desks/tables, learning media uses LCD and writing uses a whiteboard. As well as to support extracurricular activities they have a sports building as well (GOR) and can be used or used for istighatsah (Hidayati, 2016).

\section{CONCLUSION}

The study of Kiai's leadership in facing the globalization of education in Islamic boarding schools by taking data sources from the boarding school al-Hikmah 2 Benda Sirampog Brebes, changes that usually occur from the globalization process of education which is certainly influenced by Kiai's leadership as the founder and caretaker of the boarding school from generation to generation there has never been a struggle for leadership. Although there are still some misunderstandings, this can be resolved through deliberation and division of tasks in accordance with the proportions. The Kiai leadership process prioritizes and prioritizes heredity. Genealogy is one of the processes to make a pesantren leader because the main priority of a pesantren leader is the descendants of the pesantren's founders. If the descendant is not found to be a leader, there will be a replacement from the family or son-in-law by fulfilling the requirements which include; exemplary, authority, charisma, scholarship, personality, sincerity, managerial and social skills. For example, there is no descent, then someone else who is considered capable with sincerity is appointed to accept the mandate. The impact of changes in pesantren education can be seen from the attitude of the Kiai and the pattern of Islamic boarding school education towards changes that occur in the world of education. Education was then developed in the al-Hikmah 2, al-Asy'aritah and al-Fadlu pesantren. The pattern is designed in various ways according to the needs of the times. The Kiai's mindset is al-mukhafadha al-qadimi pious, that is, the existence of pesantren from ancient times is the same as the existing pesantren that exist today, meaning that it is in order to maintain the pure tradition of pesantren which is still relevant to a constructive change.

\section{REFERENCES}

Arifin, Zainal. 2015. Kepemimpinan Kiai Dalam Ideologisasi Pemikiran Santri Di Pesantren-pesantren Salafiyah Mlangi Yogyakarta. Inverensi: Jurnal Penelitian Sosial Keagamaan, 9(2), 27-38.

Azra, Azzumardi. 2009. Pendidikan Islam di Era Globalisasi Peluang dan Tantangan, Bunga Rampai Mereka Bicara Pendidikan Islam. Jakarta: Raja Grafindo Persada.

Fazriel, Armhela et al. 2015. The Role of Leader in Employee Performance Achievement Studies, in Employment Board Regional Malang. Journal Administrasi Publik, 2(4), 46-58.

Goleman et al. 2002. Primal Leadership: Realizing the Power of Emotional Intelligence. Boston: Harvard Bussines SchoolPress.

Karim, Abdul. 2018. Kepemimpinan dan Menejemen Kiai dalam Pendidikan Studi Kasus pada Pesantren Bendakerep. Gedongan dan Buntet Cirebon. Jakarta: Yayasan Hubbul Wathon,).

Khotimah, Khusnul. 2009. Islam dan Globalisasi: Sebuah Pandangan tentang Universalitas Islam. Komunika, 3(1), 114-132.

Lano, PF. 2016. Fungsi Kepemimpinan untuk Mengurangi Sikap Arogansi Pegawai, Journal Ilmu Sosial dan Ilmu Politik, 4(1), 161-173.

Ma'rufah, St. 2014. Persepsi Terhadap Kepemimpinan Kiai, Konformitas Dan Kepatuhan Santri Terhadap Peraturan Pesantren, Persona, Jurnal Psikologi Indonesia, 3(2), 76-88. 
Manuati, Dewi I Gusti Ayu. 2009. Model Kepemimpinan Efektif. Piramida: Journal kependudukan dan pengembangan sumber daya Manusia, 5(1), 54-65.

Moesa, Ali Maschan. 2007. Nasionalis Kiai, Konstruksi Sosial Berbasis Agama. Yoyakarta: LKiS Printing Cemerlang.

Moloi, K. C., Gravett, S. J., \& Petersen, N. F. (2009). Globalization and its Impact on Education with Specific Reference to Education in South Africa. Educational Management Administration \& Leadership, 37(2), 278-297. https://doi.org/10.1177/1741143208100302

Parker, L., \& Raihani, R. (2011). Democratizing Indonesia through Education? Community Participation in Islamic Schooling. Educational Management Administration \& Leadership, 39(6), 712-732. https://doi.org/10.1177/1741143211416389

Rivai, Veithzal. 2003. Kepemimpinan dan Prilaku Organisasi. Jakarta: Raja Grafindo Persada.

Spring, Joul. 2009. Globalization of Education. New York: Routledge.

Sulaiman. 2016. Kepemimpinan Kiai Dalam Transformasi Pendidikan Islam (Studi Atas Perilaku Kepemimpinan Kiai Dalam Mengelola Pondok Pesantren Di Situbondo). Falasifa, 7(2), 156-168.

Susanto, Edi. 2007. Kepemimpinan Kharismatik Kiai Dalam Perspektif Masyarakat Madura. Karsa, 11(1), 76-89.

Wayong, Muhamad. 2007. Sinergi Agama dan Sains: Suatu Paradigma Menuju Era Globalisasi Pendidikan. Lentera Pendidikan, 10(2), 25-33. 